Running head: THE WORD AND WORDS

"The Word and Words in the Abrahamic Faiths"

\author{
Linda and Larry Poston
}

Nyack College 


\begin{abstract}
Judaism, Christianity, and Islam are "word-based" faiths. All three are derived from texts believed to be revealed by God Himself. Orthodox Judaism claims that God has said everything that needs to be said to humankind - all that remains is to interpret it generation by generation. Historic Christianity roots itself in "God-breathed scriptures" that are "useful for teaching, rebuking, correcting and training in righteousness." Islam's Qur'an is held to be a perfect reflection of the "Umm al-Kitab - the "mother of Books" that exists with Allah Himself. In addition, both Christianity and Islam share the concept of "The Word" - a concept that moves the idea of communication beyond mere linguistics. Both the Scriptures and the attendant writings of these faiths (i.e., the Talmud, creeds and traditions) are all word-based documents, in many cases taking centuries to forge. This essay explores the Abrahamic faiths' characterization of "The Word" in textual form and the implications for this characterization in the culture of modern media. What is the prognosis for the future of such emphases in societies that are increasingly characterized by graphics-based media as opposed to text-based literacy? What, if anything, is lost in a media-based literacy? How are critical thinking and cognitive processes with respect to scriptural hermeneutics affected by a digital environment? How are credibility and authority maintained when the playing field is leveled for both novice and expert? Can the purveyors of the Abrahamic faiths maintain the richness of their past literary emphases and, if so, how might this be done?
\end{abstract}




\section{THE WORD AND WORDS}

"When the Lord finished speaking to Moses on Mount Sinai, He gave him the two tablets of the Testimony, the tablets of stone inscribed by the finger of God" (Exodus 31:18).

"And we impart this in words not taught by human wisdom but taught by the Spirit" (1 Corinthians 2:13)

"The Word of thy Lord doth find its fulfillment In truth and in justice: None can change His Words:

For He is the one Who heareth and knoweth all" (Surah 6: 115)

\section{The People of "the Book"}

Conventional wisdom holds that primal cultures transmitted their religious beliefs and practices mainly through oral traditions rather than through written texts. The Abrahamic faiths, however-Judaism, Christianity, and Islam—are all "word-based" faiths in the sense of having always emphasized written language. Both the Scriptures and the attendant writings of these faiths (i.e., the Talmud, creeds, catechisms, theological treatises and other such works) are all word-based documents which in many cases took centuries to forge. Indeed, both Christianity and Islam share the concept of "The Word" as an idea transcending mere linguistics.

This is not to say that the Abrahamic faiths have never had oral traditions. The Hebrew religion, for instance, consisted of two streams: the written Torah and the oral Torah, or Midrash. Muslims developed their ahadith — traditions regarding the Prophet Muhammad's life. But since the Hebrew and the Muslim oral traditions were eventually reduced to writing, our chief contention is further supported: in these religions, writing has always been preferred to orality.

\section{Word and Words in the Hebrew Religion}

The Jewish Tanakh (an acronym for Torah, Nevi'im, and Ketuvim - the three sections of the Hebrew scriptures) is filled with references to books and commands to "Write!" Early in Genesis we find "...the book (Hebrew sēper) of the generations of Adam ..." (5:1). In Exodus comes a specific command from God to write (Hebrew kātab): “... the Lord said to Moses, 


\section{THE WORD AND WORDS}

'Write this on a scroll as something to be remembered and make sure that Joshua hears it..."

(17:14). In Exodus we also find the ultimate form of writing in the Tanakh: "When the Lord finished speaking to Moses on Mount Sinai, He gave him the two tablets of the Testimony, the tablets of stone inscribed by the finger of God"' (31:18).

Words written down at God's behest were considered covenantal in form: "Then the Lord said to Moses, 'Write down these words, for in accordance with these words I have made a covenant with you and with Israel" (Exodus 34:27). God's commandments were to be "written on the doorframes of your houses and on your gates" (Deuteronomy 6:9), and when the children of Israel entered the promised land, God's law was to be written on stones coated with plaster (Deuteronomy 27:2-4).

Israel's religious officials were to avail themselves of words in a variety of ways: "The priest is to write these curses on a scroll and then wash them off into the bitter water. He shall have the woman drink the bitter water that brings a curse, and this water will enter her and cause bitter suffering" (5:23-24). The same was true of political leaders: the king of Israel was to "write for himself on a scroll a copy of this law...It is to be with him, and he is to read it all the days of his life so that he may learn to revere the Lord his God and follow carefully all the words of this law..." (Deuteronomy 17:18-19). By Joshua's time, religious writings were a ubiquitous part of Israeli culture: "Do not let this Book of the Law depart from your mouth; meditate on it day and night, so that you may be careful to do everything written in it..." (1:8).

There were books of "the chronicles of Israel" and "the chronicles of Judah" (1 Kings and 2 Kings passim) - in-house records of wars and other events involving the Jewish people. There was "the book of the annals of the kings of Media and Persia" (Esther 10:2), demonstrating that God's purview stretched beyond the Israelites. There were the books of 


\section{THE WORD AND WORDS}

Nathan and Shemaiah the prophets, and of Gad and Iddo the seers (1 Chr. 29:29; 2 Chr. 12:15). There was the book of Jehu (2 Chr. 20:34) and the book of "the vision of Nahum the prophet" (Nah.1:1). The words God spoke to Jeremiah were to be written in a book (Jeremiah 30:2), and the revelation to Habakkuk was to be "made plain on tablets..." (Habakkuk 2:2).

Ominously, there was a "book of the Wars of the Lord" (Numbers 21:14-15), but there was/is also a heavenly "book of remembrance" written in the presence of God "concerning those who feared the Lord and honored His name" (Malachi 3:16).

Genealogies were recorded in books, people were "blotted out of" books, and divisions of land were noted in books (Josh.18:9). Songs were to be written (Deuteronomy 31:19), complex prophetic names were to be recorded (Isaiah 8:1), oracles were to be inscribed on tablets and scrolls (Isaiah 30:8), and the design of the Temple as well as all of its laws and regulations were to be written for the people (Ezekiel 43:11).

\section{Word and Words in the Christian Religion}

Historic Christianity has rooted itself in its "God-breathed scriptures" that are "useful for teaching, rebuking, correcting and training in righteousness" (2 Timothy 3:16-17). The New Testament continues an emphasis on the importance of books. Revelation, for instance, speaks of

1. "a scroll (Greek.: biblion) with writing on both sides and sealed with seven seals," recording eschatological events to come (5:1).

2. books recording the deeds of every human being who has ever lived (20:12) — providing the basis for God's judgment of each.

3. the Book of Life (20:12) — with the names of those who will live eternally with God. 


\section{THE WORD AND WORDS}

In Christian circles words of God are to be written as Revelation 1:11 insists, where "someone like a son of man" commanded that John should "write (Greek.: graphō) on a scroll what you see and send it to the seven churches..." This command is repeated in Rev. 14:13: "Write: Blessed are the dead who die in the Lord from now on." Again in Rev. 19:9: "Write: Blessed are those who are invited to the wedding supper of the Lamb! ... 'These are the true words of God."' And one final time in Rev. 21:5: "Write this down, for these words are trustworthy and true."

The entire New Testament is comprised either of letters written to churches and individuals, or of treatises and narratives provided as historical records and doctrinal teaching. Matthew, Mark, Luke, John, Paul, James, Peter and Jude: all of these individuals_from fishermen to rabbi-were convinced of the necessity of written words. Paul, for instance, demonstrated his preoccupation with books when he instructed Timothy "When you come, bring...my scrolls, especially the parchments..." (2 Timothy 4:13).

Assuming primacy in the New Testament is the idea of The Word (Greek: logos), applied to Jesus the Messiah, the Son of God and second member of the Trinity. John 1 introduces the incarnational aspects of this concept: "In the beginning was the Word, and the Word was with God, and the Word was God. He was with God in the beginning. Through him all things were made; without him nothing was made that has been made... The Word became flesh and made his dwelling among us. We have seen his glory, the glory of the One and Only, who came from the Father, full of grace and truth" (John 1:1-3, 14). The term appears again in Revelation, when at His second advent Jesus appears "dressed in a robe dipped in blood... his name is the Word of God"' (Revelation 19:13). 


\section{THE WORD AND WORDS}

With the concept of "the Word incarnate" the concept of religious communication is elevated considerably. As the book of Hebrews states: "In the past God spoke to our forefathers through the prophets at many times and in various ways, but in these last days he has spoken to us by his Son, whom he appointed heir of all things and through whom he made the universe" (Hebrews 1:1-2). Here we have moved beyond the idea of God's word as "living and active, sharper than any double-edged sword, penetrating even to dividing soul and spirit, joints and marrow; judging the thoughts and attitudes of the heart" (Hebrews 4:12), which—albeit metaphorically — is still speaking of written words. In the Johannine passages, we see an incarnation of the Word in the person of Christ himself. Here the life — and death—of a man speaks, and this speaking is inscribed not onto "tables of stone" or animal skin, but flows directly from one perfect Being to finite, imperfect, and infinitely lesser beings.

\section{Word and Words in the Islamic Religion}

Islamic theology teaches that the Qur'an is "uncreated;" it is part of the eternal essence of Allah Himself. It is held to be the perfect reflection of the "Umm al-Kitab - the "mother of Books" that exists with Allah (see Surah 13:39). For Muslims, the idea of a written scripture assumes tribal overtones of elitism and exclusivity, as the Qur'an speaks of the ahl al-kitab, or "the people of the Book." This designation is applied to Jews, Christians, and Muslims and is exemplified in such passages as Surah 4:171: "O People of the Book! Commit no excesses in your religion: nor say of Allah aught but the truth..."

There are few "books" mentioned in the Muslim scriptures other than the Qur'an itself. This work is itself described in a variety of ways: the book of Enlightenment (Surah 3:184); the book of Wisdom (Surah 10:1); the book "in which there is no doubt" (Surah 32:2). It is specifically for Arabic-speaking people: "Thus have We sent this down—an Arabic Qur'an-and 


\section{THE WORD AND WORDS}

explained therein in detail some of the warnings, in order that they may fear Allah, or that it may cause their remembrance of Him" (Surah 20:113). It is a "word that distinguishes good from evil" (Surah 86:13), a message to act as a guide to mankind: "Allah has revealed (from time to time) the most beautiful Message in the form of a book, consistent with itself, (yet) repeating (its teaching in various aspects) ... Such is the guidance of Allah..." (Surah 39:23). It is unchangeable: "None can change His Words: For He is the one Who heareth and knoweth all" (Surah 6:115). But it is not exhaustive: "If the ocean were ink (wherewith to write out) the words of my Lord, sooner would the ocean be exhausted than would the words of my Lord, even if we added another ocean like it, for its aid" (Surah 18:109).

There are "books of Abraham and Moses" (Surah 87:19 — the first being a mystery, since there is nothing in the Tanakh that is so labeled). And there are "books of dark prophecies" (Surah 3:184). Finally, there is the ledger of one's deeds: “Every man's fate we have fastened on his own neck: on the Day of Judgement we shall bring out for him a scroll, which he will see spread open. It will be said to him: 'Read thine own record; sufficient is thy soul this day to make out an account against thee" (Surah 17:13-14). This Book of Deeds "will be placed (before you); and thou wilt see the sinful in great terror because of what is (recorded) therein; they will say, "Ah! woe to us! What a book is this! It leaves out nothing small or great, but takes account thereof!" (Surah 18:49).

It is interesting that, similarly to Christianity, Islam applies the term "The Word" to Jesus (see Surah 3:45). The Quranic idea distinguishes itself from the Biblical concept, however, in that The Word of the Bible is an incarnational concept ("the Word was with God and the Word was God"), while in Islam the term kalima refers to a testimony, relating to one who testifies 


\section{THE WORD AND WORDS}

regarding Allah: "Allah giveth thee glad tidings of a Word (kalima-“testimony") from Him: his name will be Christ Jesus.”

\section{Images}

Written words, we have concluded, are absolutely vital to the Abrahamic faiths. Images, on the other hand - pictures, statues, and other kinds of graphical representations — were and are considered by the adherents of these religions to be problematic. In the Tanakh, for instance, images are forbidden by the Mosaic Law: "You shall not make for yourself a carved image, or any likeness of anything that is in heaven above, or that is in the earth beneath or that is in the water under the earth. You shall not bow down to them or serve them..." (Exodus 20:4). For some Jews, this prohibition applies both to the making and to the worshiping of images, while for others it forbids only the worship of them. In any case, images must be "handled with care."

In Islam as well, images are generally forbidden. While there is no direct Qur'anic prohibition, the ahadith contain several proscriptions. For instance, "Ibn Mas'ud related that he heard the Prophet (peace be upon him) say: 'The severest of penalties on the Day of Resurrection will be given to image makers"” (Sahih Bukhari). The only exceptions are images that have been formed from Arabic characters that compose Quranic verses. The Lion of the Ismaili Aga Khans is an example:

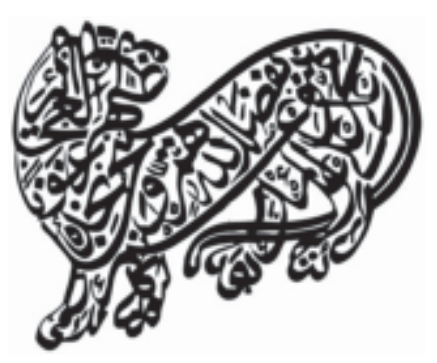




\section{THE WORD AND WORDS}

In general, Christianity has not been as harsh toward images as the other two faiths, though the denominations that have retained an emphasis on the Mosaic Law have tended to be the most restrictive. The "Iconoclastic Controversy" that led to the Seventh Ecumenical Council in $787 \mathrm{CE}$ is an example of the ambivalent attitudes Christians have displayed. Icons were permitted by the Council over the protests of the Eastern churches, which then reversed their position and became the chief advocates of iconography.

We may conclude, then, that while "words" and "books" have a long and positive tradition in the Abrahamic faiths, "images" have had a much more troubled history. In a world increasingly characterized by an emphasis on moving pictures in particular and a decline in the popularity of the printed page, such trends assume great significance for the future of religion.

\section{From Gutenberg to Gates: The Continuing Paradigm Shift}

The late Twentieth Century was not without its prophetic voices warning of the effects a shift from "books" to "screens" would have upon our culture. Science fiction writer Ray Bradbury was among the first to sound the alarm in his Fahrenheit 451. The displacement of the printed word by wall-sized television screens was graphically portrayed in a narrative in which books were recognized to have such power that governments sought to eliminate them so that absolute control over citizens could be maintained.

From a more academic perspective, University of Toronto professor Marshall McLuhan distinguished between "hot" and "cool" media. A "hot" medium (such as a book or radio) has enough detail supplied by the source that little interpretation needs to be added by the individual receiver. In contrast, a "cool” medium (an image-based medium such as television) provides only meager information and a "hazy" message, leaving much room for misinterpretation (McLuhan, 1964). 


\section{THE WORD AND WORDS}

As "hot" media, the foundational texts of the Abrahamic faiths have always been selfdefining (despite the hermeneutical problems that accompany changes in culture over time). According to McLuhan's theory, a shift of religious expressions to screen-based "cool media" would necessarily involve a change in what is communicated since such media provide so little "definition" and leave so much to the audience's imagination.

Jerry Mander amplified these ideas when he proposed Four Arguments for the Elimination of Television (1978). His first objection dealt with the sensory-deprivation that McLuhan's "cool" media produce. "Mediated experience" numbs the mind, since normal reactions (i.e., compassion, rage, indignation, arousal, etc.) to scenarios involving famine, homelessness, abuse and eroticism become ludicrous in a TV environment. No REAL action can be taken, and one therefore develops a habit of stifling emotional responses. This is proper in front of a TV screen, but when habits become so ingrained that one is equally numb in real-life situations, tragedies occur that will multiply exponentially as society adopts "cool media" as its main input source.

In Argument Three Mander showed that print media requires an individual to transform the streaks of ink forming the letters of a word into a picture created from one's own experience. With words, each individual is in control of his/her images, able to "edit" them at will. But image-based media feed images directly into the mind; they are "logged" automatically in the brain, without the possibility of refusal, editing or erasure.

A word-based religious text gives individuals the opportunity to ponder and consider how combinations of words into "sentences," "paragraphs," and "chapters" may be transformed into personal images. Creating one's own "pictures" of "God," "redemption," "savior," "salvation," and other such ideas based on scriptural texts introduces the possibility of an intimate and 


\section{THE WORD AND WORDS}

personal relationship with the Deity in ways that image-based religious systems — which provide images created by a select few — do not. It was perhaps for these reasons that "images" were considered so problematic by the Abrahamic faiths.

\section{People of the Book or People of the Screen?}

The ways that the current generation of young people "learn" have been greatly affected by an online environment that promotes information as a commodity to be acquired in the shortest amount of time possible. The increased ability to engage with and influence the outcome of one's "screen time" has produced a "customized" and "multi-tasking" approach to information and learning, the chief characteristics of which are as follow.

Speed

"Screen media" is best suited for information retrieval. The online environment lends itself to "surfing" and rapid retrieval of "facts," but discourages the kind of reflective thinking that "hot media" requires. As most librarians know, students looking for articles for a research paper due the following day will use the first two items produced by a search rather than taking the time to scroll to the second or third pages of results, thereby often missing many more relevant articles. As Christine Rosen notes in "People of the Screen:" "librarians teach computer research skills to young people who extract information like 'miners.' But young people are not like real miners, who dig intentionally and carefully. They are more like '49ers panning for gold. To be sure, a few will strike a vein, stumbling across an item so engrossing that they will seek more. But most merely sift through the silty top layers, grab what is shiny and close at hand, and declare themselves rich" (Rosen 2008).

Another problem with "quick retrieval" is seen in a 2006 study demonstrating that only $16 \%$ of readers read a text linearly (i.e., word by word and sentence by sentence). Instead, 


\section{THE WORD AND WORDS}

reading a screen according to the shape of an "F" is the norm. Most people read across the top of a page, then scan down the left side of the screen, slowing a bit mid-page to read a line or two horizontally and then returning to the left side. Content at the lower-right portion of the screen is not read carefully or at all (Bauerlein 2009).

While such "information retrieval" may be swifter, several studies have shown that online, actual reading takes place much more slowly. Web designer J. Nielson, for instance, discovered that "reading from standard computer displays is about 20 percent slower and more error prone than reading on paper" (Nielsen 2000).

Religiously-oriented screen readers will need to be able to decide when "fast and easy" should not be a priority. Logos Software, for instance, allows one to search a Greek word appearing in the New Testament and see all the passages in which it has been used, along with corresponding commentaries on these passages. Such resources can be "exciting" and give one a sense of being a "true student of religion." But once such information has been retrieved, one must "meditate" (i.e., use reflective thinking) to make practical use of it. And "reflective thinking" is not an item supplied by computer software.

\section{Experience}

Screen reading allows one to determine his/her "journey" by allowing one to click on supplemental links to see definitions or additional readings related to the original document. But the composition of many current webpages invites one also to click on an ad or check Facebook or email. Such a "helter-skelter" approach to gathering information in the long run is very distracting and produces a sense of dissatisfaction. Why? "The process [of online searching] involves so much physical manipulation of the computer that it interferes with our ability to 


\section{THE WORD AND WORDS}

focus on and appreciate what we're reading; online text moves up and down the screen and lacks physical dimension, robbing us of a feeling of completeness..." (Ballantyne 2008).

Such frenetic search activity has physiological as well as psychological effects: "People of the screen... are exposing themselves to excessive amounts of dopamine, the natural chemical neurotransmitter produced by the brain. This in turn can lead to the suppression of activity in the prefrontal cortex, which controls functions such as measuring risk and considering the consequences of one's actions" (Rosen 2008). Additionally, impairment of the ability to "consider the consequences of one's actions" certainly strikes at the heart of one of the most important functions of a religious system: the equipping of devotees with the ethical precepts necessary for proper integration into human social groupings.

In contrast, reading a printed book or document promotes a fixed context. As Johns Hopkins historian David Bell states, "when reading, you should not be the master; you should be the student. Surrendering to the organizing logic of a book is, after all, the way one learns" (Rosen 2008). Approaching a religious text in a studious manner creates a meditative and submissive environment within which "considering the consequences of one's actions" becomes natural.

\section{Entertainment}

Older teachers and administrators often assume that younger generations of students view laptop computers, iPads and other such technology in the way that the "transitional generation" does: as a glorified typewriter and serious research tool that greatly enhances the ability to retrieve, produce, edit, and print written words. But for young people such devices are almost never seen as "work machines" but rather as "toys"-items for entertainment, pleasure, and leisure time activities. 


\section{THE WORD AND WORDS}

If the primary use of "cool” technology is associated with leisure, how can we expect an attitude of respect and reflective thinking to be applied to online texts-especially scriptural texts? In comparison with a fast-paced video game, for instance, reading "scripture" online in a linear fashion is a laborious and boring experience. The question then arises: since web technology lends itself to such "distractions" and a constant stream of images instead of fixedcontent words, would it be advisable to augment scriptural texts with cross-reference links that provide definitions, timeline graphics and other appropriate visuals to provide a customized approach to "experiencing" texts? Or would such augmentation instead hinder the ability to analyze texts sequentially and to understand the context of the writings?

\section{$\underline{\text { Perpetual Partial Attention }}$}

With respect to the younger generation's claim to be expert "multi-taskers," a twothousand year old quote from the Roman philosopher Seneca still applies today: “To be everywhere is to be nowhere." The Millennial generation has often been praised for their ability to multi-task while online, but research shows that "people who juggle many tasks are less creative and less productive than those who do one thing at a time... The common thread in these disabilities is the division of attention. The richness of our thoughts, our memories and even our personalities hinges on our ability to focus the mind and sustain concentration.... (Carr 2010).

In the rich tradition of highly focused meditation on scripture texts seen in all three of the Abrahamic faiths, is there room for a multi-tasking approach? Can the ability to "shepherd disjointed bits of information" be transmuted into an ability to shepherd conscientiously a congregation of religious devotees? Available research does not give much room for optimism with respect to these questions. 


\section{THE WORD AND WORDS}

\section{Facing the Future: Possible Effects of Visual/Digital/Graphic Images on}

\section{Adherents of the Abrahamic Religions}

New York Times writer Kevin Kelly predicts that images may well become the dominant form of communication for future cultures. "A new distribution-and-display technology is nudging the book aside and catapulting images, and especially moving images, to the center of the culture. We are becoming people of the screen....We are now in the middle of a second Gutenberg shift - from book fluency to screen fluency, from literacy to visuality" (emphasis added) (Kelly 2008).

As intimated above, a constant bombardment of images, ads, and links promotes a "surfer" mentality in which one only skims the surface of whatever is being explored. In addition, the desire to be entertained reinforces shallow thinking, and constant access to information discourages memorization as something non-essential. The very title of Mark Bauerlein's The Dumbest Generation (2008) could be a sobering prophecy of things to come.

With the ease of texting through cellphones, the younger generation often turns to peers for information or for determining what to think or believe about something rather than going through a process of reflective thinking. They have little patience or motivation to distinguish "expert" from "novice" as they evaluate the truth and validity of information. Primary sources of information will increasingly become a fluid and "generic" online potpourri of authoritative and credible information often indistinguishable from "misinformation" or outright falsehood.

If children grow up primarily using an online environment for learning, they will most likely continue to seek visual stimulation and packaged programs for "edutainment" even in their adult years. As a result, reflective reading of longer printed volumes such as the Bible or the Qur'an may decline precipitously. In quoting a 1988 essay of critic George Steiner, Christine 


\section{THE WORD AND WORDS}

Rosen speculates about the possible development of what might be considered a new form of monasticism:

[Steiner says] "I would not be surprised if that which lies ahead for classical modes of reading resembles the monasticism from which those modes sprung. I sometimes dream of houses of reading - a Hebrew phrase - in which those passionate to learn how to read well would find the necessary guidance, silence, and complicity of disciplined companionship" ... To those raised to crave the stimulation of the screen, Steiner's houses of reading probably sound like claustrophobic prisons. For those raised in the tradition of print literacy, they may seem like serene enclaves, havens of learning and contentment, temples to the many and subtle pleasures of the word on the page. In truth, though, what Steiner's vision most suggests is something sadder and much more mundane: depressing and dwindling gated communities, ramshackle and creaking with neglect, forgotten in the shadow of shining skyscrapers. Such is the end of the tragedy we are now witness to: Literacy, the most empowering achievement of our civilization, is to be replaced by a vague and ill-defined screen savvy. The paper book, the tool that built modernity, is to be phased out in favor of fractured, unfixed information. All in the name of progress.” (Rosen 2008).

\section{Conclusions}

In the near future the authors believe that we are going to find it necessary to teach young people the meaning and usage of "words." It will be necessary to educate them regarding the importance of "printed pages" collected into "books," and to demonstrate for them in graphic 


\section{THE WORD AND WORDS}

detail how essential it is to retain personal control over the images logged permanently in their minds instead of giving over that control to media sources that have dubious agendas.

If we can retain an emphasis on "words" as opposed to "images," we may see a continuation of the Abrahamic religions as they have existed in the past, with the profound influences they have exercised over Western and Middle-Eastern civilizations. If, however, we see a continual shift to an image-based culture along with a lessening of emphasis on the "hot media" of the printed word, we predict that there will be an increasingly secular orientation with respect to human thought.

We believe that at the same time it will be necessary to concentrate on teaching young people how to make words out of images. One picture is NOT "worth a thousand words" unless one can formulate sentences and paragraphs that will interpret the image in question, making it meaningful to a larger audience than simply one's inner self. This, of course, is one of the main purposes of religion in general: to make sense of and bring meaning to the time and space which any particular portion of humanity occupies. Let us not allow contemporary culture to rob us of the richness and functionality of our religious heritage through its propensity for submerging or eliminating meaning from human life.

\section{Author Note}

Linda Poston is Dean of Library Services at Nyack College in Nyack, New York. She holds a M.L.S. in Library Science from Long Island University. She served for 8 years on the Board of Directors of the Association of Christian Librarians (including a term as President) and for 12 years on the Executive Board (including a term as President) of the Westchester Academic Library Directors Organization (WALDO), a regional academic library consortium. 


\section{THE WORD AND WORDS}

Larry Poston is Chair of the Department of Religion and Professor of Religion at Nyack College in Nyack, New York. He holds a Ph.D. in the History and Literature of Religions from Northwestern University (Evanston, IL) and is the author of Islamic Da'wah in the West: Muslim Missionary Activity and the Dynamics of Conversion to Islam (Oxford University Press, 1992), The Changing Face of Islam in America (Horizon Books, 2000), and numerous articles. 
THE WORD AND WORDS

\section{References}

Ballantyne, C. (2008, December 23). “Online v. print reading: which one makes us smarter?” [Web log post]. Retrieved from http://www.scientificamerican.com//.cfm?id=online-vprint-reading-which-one

Bauerlein, M. (2009, October 21). "Screen reading and print reading” [Web log post]. Retrieved from The Chronicle of Higher Education: Brainstorm: http://chronicle.com///screenreadingprint-reading/

Bauerlein, M. (2008). The dumbest generation: How the digital age stupefies young Americans and jeopardizes our future. New York, NY: Penguin Group.

Carr, N. (2010, June 5). “Does the internet make you dumber?” Wall Street Journal. Retrieved from http://online.wsj.com//.html

Kelly, K. (2008, November 23). "Becoming Screen Literate.” New York Times. Retrieved from http://www.nytimes.com/////wwln-future-t.html?pagewanted=print

Mander, Jerry (1978). Four Arguments for the Elimination of Television. New York: Quill.

McLuhan, Marshall (1976). Understanding Media: The Extensions of Man. New York: McGraw-Hill.

Nielsen, J. (2000). Designing web usability. Indianapolis, IN: New Riders.

Rosen, C. (2008 Fall). "People of the Screen.” The New Atlantis: A Journal of Technology \& Society. Retrieved from http://www.thenewatlantis.com/ications/_detail.asp?id=452\&css=print 